\title{
(1)
}

\section{ANTIBACTERIAL EFFECTS OF EXTRACTS FROM Tanacetum parthenium L. LEAVES}

\section{Zewditu Shiferaw ${ }^{1}$ Sasikumar J. M.*2, Ameha Kebede ${ }^{2}$ and Endale Teju ${ }^{3}$}

Address (es): Dr. Jagathala Mahalingam Sasikumar,

${ }^{I}$ Department of Biology, Jigjiga University, Ethiopia. Phone number: +251 921267311.

${ }^{2}$ School of Biological Sciences and Biotechnology, Haramaya University, Ethiopia, Phone number: +251 931907923.

${ }^{3}$ Department of Chemistry, Haramaya University, Ethiopia, Phone number: +251911182609.

*Corresponding author: jmsashikumar@gmail.com

\section{ABSTRACT}

https://doi.org/10.36547/be.394

In our current study, phytochemical analysis and antibacterial activity of leaf extracts of T. parthenium were assessed. Qualitative phytochemical screening was carried using standard procedures and quantitative analysis for estimation of total phenolic content (TPC) was determined by spectrophotometric method. The antibacterial activity was accomplished using disc diffusion assay, determination of minimum inhibitory concentration (MIC) and minimum bactericidal concentration (MBC) against two gram positives (Streptococcus pyogenes (ATCC 19615), Streptococcus anginosus) and two gram negatives (Pseudomonas aeruginosa (ATCC 27853) and Fusobacterium necrogenes) pathogenic bacteria. Preliminary phytochemical analysis of the plant extracts revealed the presence of phenolics, tannins, flavonoids, terpenoids, and cardiac glycosides. The methanol extract had highest total phenolic content $(6.17 \pm 0.19 \mathrm{mg} / \mathrm{ml})$. The results also displayed that the methanol extract exhibited significant antibacterial activity against the tested pathogenic microorganisms, in particular against S. anginosus with inhibition zone of $15.33 \pm 0.33$ mm. The lowest MIC $(33.33 \mathrm{mg} / \mathrm{ml})$ and MBC $(41.66 \mathrm{~g} / \mathrm{ml})$ values were observed in methanol extract against $S$. anginosus and S. pyogenes respectively. The results indicated that crude leaf extracts of $T$. parthenium had a potent antibacterial activity suggesting that it could be valuable in treating pathogenic bacterial infections.

Keywords: bacterial pathogens, gram positive, gram negative, minimum inhibitory concentration, minimum bactericidal concentration, phytoconstituents, Tanacetum parthenium

\section{INTRODUCTION}

Since time immemorial, plants have been used as source of remedies for the treatment of several ailments including infectious diseases by the people of all parts the world. Despite the advent of several chemically synthesized medicines, infectious diseases are still treated by medicinal plants. Infection causing pathogenic microbes have developed resistance against the synthetic antibacterial drugs (Andersson and Hughes, 2010, De Zoysa et al., 2019). Moreover, side effects of practice of these drugs have amplified (Tsuruga, 2007). These motives have driven researchers to hunt for novel antimicrobial agents from plants substitute to synthesized chemical drugs and numerous studies were reported on the antibacterial activities of the medicinal plants (Sasikumar et al., 2007, Costa et al., 2017). Keeping this in mind, in the current investigation, T. parthenium (Asteraceae) was evaluated for its antibacterial activity against certain bacterial pathogens. The plant was reported to contain sesquiterpene lactones (predominantly parthenolide), flavonoids and essential oils (Knight, 1995, Bernath, 2000, Burt, 2004, Izadi et al., 2010, Shahhoseini et al., 2019). The sesquiterpene lactones from this plant showed significant inhibitory effects on pathogenic microorganisms (Marilena et al., 2005, Ahmad, 2010). Essential oil from T. parthenium exhibited considerable antimicrobial activities against several human pathogenic bacterial strains (Zahra et al., 2013). A multitude of works regarding the antibacterial screening of $T$. parthenium have been reported elsewhere (Izadi et al., 2010, Alodera et al., 2012, Goren et al., 2013, Stanković et al., 2016). Nevertheless, no literature occurs regarding the antibacterial activity of T. parthenium from Ethiopia. The general goal of this current study is to analyse the phytochemical analysis and to assess antibacterial properties of various extracts of $T$. parthenium leaves against two gram positive and two gram negative bacterial pathogens.

\section{MATERIALS AND METHODS}

\section{Preparation of extracts}

The leaves of $T$. parthenium were collected from premises of Haramaya University, Ethiopia. The plant specimen was identified with assistance of taxonomic experts of School of Biological Sciences and Biotechnology and deposited in the Haramaya University herbarium. The collected leaves were dried and pulverized. The leaf powder $(40 \mathrm{~g})$ was exhaustively extracted with $200 \mathrm{~mL}$ $(1: 5 \mathrm{v} / \mathrm{v})$ of hexane, chloroform, methanol and water successively using Soxhlet apparatus. The solvent and aqueous extracts were filtered and the filtrates were condensed to dryness at $40 \pm 10^{\circ} \mathrm{C}$ by rotary flash evaporator (Buchi type rotavapor) under reduced pressure. The resultant crude extracts were kept at $4^{\circ} \mathrm{C}$ until further use. The extracts were then used to detect the phytochemicals, to measure total phenolics and to determine antibacterial activity against dental pathogens.

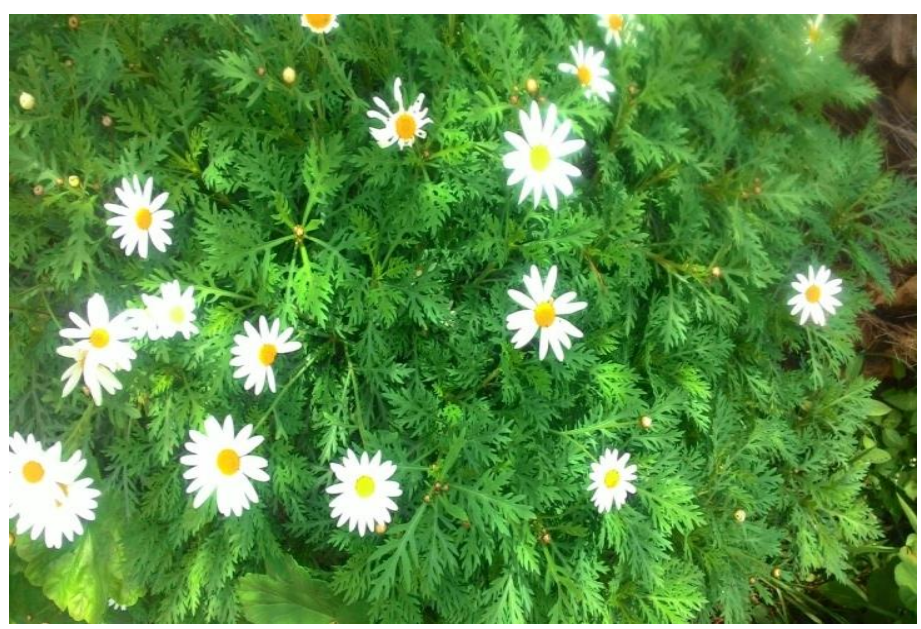

Figure 1 Image of Tanacetum parthenium $\mathrm{L}$.

\section{Qualitative analysis}

Qualitative analysis of crude extracts of leaves of T. parthenium were performed to detect various bioactive compounds such as alkaloids, steroid, flavonoid, saponin, phlobatannins, tannin, terpenoids and phenolic compounds (Adachukwu et al., 2013, Ajayi et al., 2011, Harborne, 1991, Shaik et al., 2011).

\section{Test for alkaloids}

The presence of alkaloid in the crude extract was detected using Mayer's reagent. Briefly, $2 \mathrm{ml}$ of $1 \% \mathrm{HCl}$ was added to $6 \mathrm{ml}$ of each concentrated extract in different test tubes. Each mixtures were heated for 2 minutes in water bath. Then, it was cooled and filtered, $1 \mathrm{ml}$ of the filtrate was treated with $0.5 \mathrm{ml}$ Mayer's reagent, Formation of creamy yellow precipitate confirmed the presence of alkaloids. 


\section{Test for Steroids and Sterols}

To test the presence or absence of steroids and Sterols, Salkowski's test was employed. Briefly, 0.5 gram the crude extracts was dissolved in $2 \mathrm{ml}$ of chloroform and add 10 drops acetic acid. Then, $2 \mathrm{ml}$ of concentrated sulphuric acid was added by the sides of the test tube. The upper layer turns red to blue which revealed the presence of steroid and sterols compounds.

\section{Test for Tannins and phenolic compounds}

To confirm the presence or absence of tannins, 0.5 gram of each extract was added into $20 \mathrm{ml}$ of distilled water in test tubes separately. The mixtures were boiled in water bath for 5 minutes and filtered. After cooling, $1 \mathrm{ml}$ of the filtrate was diluted to $5 \mathrm{ml}$ of distilled water and a few drops of $10 \%$ ferric chloride was added. Formation of brownish-green precipitate indicated presence of tannins. Similarly, one $\mathrm{ml}$ of the extract was treated with a few drops 5\% ferric chloride solution; a dark green colour revealed the presence of phenolic compounds.

\section{Test for fixed oils and fats}

Test for fixed oils and fats were done using the spot test. A small quantity of extract was pressed between two-filter papers. Oil stains on filter paper indicated the presence of fixed oil.

\section{Test for cardiac glycosides}

The presence of cardiac glycosides in the crude extracts was detected using Legal's test. In brief, 0.5 gram of the crude extract was treated with few ml pyridine, 2 drops of sodium nitroprusside and a drops of $20 \% \mathrm{NaOH}$ solution. Formation of deep red colour indicated the presence of cardiac glycosides.

\section{Test for saponins}

The presence of saponin was detected using foam test. Briefly, 0.5 gram of each powdered sample was placed into separate test tubes and mixed with $20 \mathrm{ml}$ of distilled water. The mixture was boiled in water bath for 10 minutes and filtered. After cooling, $2 \mathrm{ml}$ of filtrate was added to a test tube and diluted to $10 \mathrm{ml}$ with distilled water. It was shaken vigorously for 2 minutes. Formation of froth indicated the presence of saponin in the crude extracts.

\section{Test for flavonoids}

To confirm the presence of flavonoids, $2 \mathrm{ml}$ of each of concentrated crude extracts was added into different test tubes. $5 \%$ of lead acetate solution was added. Formation of yellow colour precipitate confirms the presence of flavonoids.

\section{Test for terpenoids}

To detect the presence of terpenoids in the crude extract, Salkowski's test was used. $2 \mathrm{ml}$ of each concentrated extract was mixed with $2 \mathrm{ml}$ of chloroform in separate test tubes, then $2 \mathrm{ml}$ of sulfuric acid was added carefully. A reddish rown coloration indicated the positive result of terpenoids.

\section{Test for Phlobatannins}

To confirm the presence or absence of Phlobatannins, 0.2 gram of each solidified extracts was placed into separate test tubes and mixed with $10 \mathrm{ml}$ of distilled water. The mixtures were boiled in water bath for 10 minutes. After cooling each mixture was filtered through a what man No.1 filter paper. Next $2 \mathrm{ml}$ of $1 \%$ HCL was added to each mixture Development of red precipitate indicate presence of Phlobatannins.

\section{Quantitative analysis}

\section{Determination of total phenolic content (TPC)}

The total phenolic content (TPC) in the extracts was estimated calorimetrically by folin-ciocalteu phenol reagent method using gallic acid as standard based on the method proposed by Singleton et al. (1999). Briefly, diluted extract $(1 \mathrm{~mL})$ was added with diluted folin-ciocalteu reagent $(5 \mathrm{~mL})$. After 3 minutes of reaction, 4 $\mathrm{ml}$ of $7.56 \% \mathrm{NaCO}_{3}$ was added and the mixtures were incubated for 60 minutes at room temperature. The absorbance was read at $765 \mathrm{~nm}$ against blank solution using
UV-Visible spectrophotometer. The analysis were performed in triplicates. The TPC was expressed as mg of gallic acid equivalents from a gallic acid standard curve (mg GAE/gm crude extracts). The concentration of total phenolics in the extracts were derived from a standard curve of gallic acid ranging from 10 to 70 $\mu \mathrm{g} / \mathrm{mL}(r 2-0.9899)$ (Figure 2.).

\section{Evaluation of antibacterial activity}

\section{Pathogenic bacterial strains}

The selected two gram positives (Streptococcus pyogenes (ATCC 19615), Streptococcus anginosus) and two gram negatives (Pseudomonas aeruginosa (ATCC 27853) and Fusobacterium necrogenes) pathogenic bacteria that causes human infections were used for the antibacterial bio-assays. The strains were obtained from Ethiopian Biodiversity Institute (EBI), Addis Ababa, Ethiopia. The bacterial turbidity of each of bacterium was prepared and standardized by following the guideline of Clinical and Laboratory Standard Institute (CLSI, 2012).

\section{Disc diffusion assay}

The in-vitro antibacterial activities of the crude extracts of the leaves of $T$. parthenium at different concentrations were studied by disc diffusion method against various human bacterial pathogens (CLSI, 2012). The bacterial cultures were grown in nutrient agar by transferring $25 \mathrm{ml}$ into a pre-sterilized Petri dish and allowed to solidify at room temperature for 1 hour. Then $0.1 \mathrm{ml}$ suspension of the target pathogenic bacteria cultures were spread plated onto Muller Hinton agar. The tterile filter paper discs $(6 \mathrm{~mm})$ each impregnated with $0.1 \mathrm{ml} /$ disc of different crude extracts $(100 \mathrm{mg} / \mathrm{ml}, 150 \mathrm{mg} / \mathrm{ml}$ and $200 \mathrm{mg} / \mathrm{ml})$ were placed onto the agar surface at equidistance and the petridishes were incubated at $37^{\circ} \mathrm{C}$ for $24 \mathrm{hrs}$. A paper disc containing standard antibiotic was used as a positive control Chloramphenicol $(25 \mu \mathrm{g} / \mathrm{disc})$. The experiment was done in triplicates under sterile conditions. The antibacterial effect was determined by measuring diameter of clear inhibition zones.

\section{Determination of Minimum Inhibitory Concentration (MIC) and Minimum Bactericidal Concentration (MBC)}

The minimum inhibitory concentrations (MIC) and Minimum Bactericidal Concentration (MBC) of the four crude extracts of the leaves of T. parthenium was determined by broth dilution technique according to the Clinical and Laboratory Standards Institute (CLSI, 2012). Extract concentrations ranging from 3.125 to $100 \mathrm{mg} / \mathrm{mL}$ were prepared and $0.1 \mathrm{ml}$ of each dilution were added to the different test tubes.

\section{Statistical analysis}

All determinations were carried out in triplicate and the results were presented as mean values \pm SD. Differences between means were evaluated using one-way analysis of variance ANOVA provided by SPSS. $P$ - values $\leq 0.05$ were considered as showing significance difference.

\section{RESULTS}

\section{Qualitative and Quantitative analysis}

The findings of the qualitative analysis of the crude extracts of the leaves of $T$. parthenium are recorded in Tab 1 . The results showed that the polar and non-polar solvent (hexane and chloroform) extracts revealed the presence of flavonoids, terpenoids, and cardiac glycoside whereas phenolics, tannins, alkaloids, phlobatannins, saponin, fats and oils were found absent. The polar extracts (methanol and aqueous) possess flavonoids, terpenoids, glycosides, phenolics, tannins, steroids. Alkaloids, phlobatannins, saponin, fats and oils were found absent in the polar extracts. Tab. 2 précises the results of quantitative phytochemical analysis of the solvent and aqueous extracts of the leaves of T. parthenium. A significantly higher TPC was reported in methanol extract $(6.17 \pm 0.19 \mathrm{mg} / \mathrm{g}$ Gallic acid equivalent) while the lowest in water extract $(1.07 \pm 0.16 \mathrm{mg} / \mathrm{g}$ Gallic acid equivalent $)(\mathrm{p} \leq 0.05)$. The value of total phenolic contents (TPC) ranged in the following decreasing order; methanol extract $<$ hexane extract $<$ chloroform extract $<$ water extract. 
Table 1 Qualitative analysis of leaf extracts of T. parthenium

\begin{tabular}{|c|c|}
\hline Extracts & Secondary metabolites \\
\hline Hexane & Flavonoids, terpenoids, glycosides \\
\hline Chloroform & Flavonoids, terpenoids, glycosides \\
\hline Methanol & $\begin{array}{c}\text { Flavonoids, terpenoids, glycosides, phenolics, tannins, ster } \\
\text { oids }\end{array}$ \\
\hline Water & $\begin{array}{c}\text { Flavonoids, terpenoids, glycosides, phenolics, tannins, ster } \\
\text { oids }\end{array}$ \\
\hline
\end{tabular}

Table 2 Quantitative analysis of leaf extracts of T. parthenium extracts

\begin{tabular}{lc}
\hline Solvent extract & TPC $(\mathbf{m g} / \mathbf{g})^{*}$ \\
\hline Hexane & $2.21 \pm 0.94^{\mathrm{a}}$ \\
Chloroform & $2.12 \pm 0.48^{\mathrm{a}}$ \\
Methanol & $6.17 \pm 0.19^{\mathrm{b}}$ \\
Water & $1.07 \pm 0.16^{\mathrm{c}}$ \\
\hline
\end{tabular}

Legend: Mean values \pm standard deviations $(n=3)$ with the same small letters superscript within the same column are not significantly different at $\mathrm{p}>0.05$.

Whereas mean values \pm standard deviations followed by different small letters superscript within the same columns are significantly different at $\mathrm{p} \leq 0.05$. TPC Total phenolic content. *Gallic acid equivalent

Antibacterial activity against the bacterial pathogens

\section{Disc diffusion assay}

The antibacterial activities of the extracts of $T$. parthenium against the microorganisms examined in this study were assessed by measurement of inhibition zones, as well as by MIC and MBC values. Chloramphenicol was used as a standard positive control. Our results exhibited that all the four extracts of $T$. parthenium displayed moderate to good antibacterial activities against the test pathogens (Tab. 3). Among these leaf extracts tested, the highest antibacterial activities were exhibited by methanol $(15.66 \pm 0.33 \mathrm{~mm})$ and water extracts
$(15.33 \pm 0.33 \mathrm{~mm})$ at a concentration of $200 \mathrm{mg} / \mathrm{ml}$ against the gram positive $S$. anginosus. From the four pathogens, $S$. anginosus was the most susceptible tested bacterial strain at the concentration of $200 \mathrm{mg} / \mathrm{ml}$ of methanol extract with the zone of inhibition $15.66 \pm 0.33 \mathrm{~mm}$, followed by $S$. pyogenes with $15.00 \pm 0.00 \mathrm{~mm}$, while the less susceptible was the gram negative $P$. aeruginosa with $12.00 \pm 0.00 \mathrm{~mm}$. Aqueous crude extract also recorded a significant antibacterial activities against $S$. anginosus, $S$. pyogenes, $F$.necrogenes and $P$. aeruginosa with the zone of inhibitions of $15.33 \pm 0.33 \mathrm{~mm}, 14.00 \pm 0.57 \mathrm{~mm}, 12.00 \pm 0.00 \mathrm{~mm}, 11.66 \pm 0.88 \mathrm{~mm}$ respectively at the concentration of $200 \mathrm{mg} / \mathrm{ml}$. The chloroform extract recorded good antibacterial activity against tested pathogenic bacterial strains $S$. anginosus, $S$. pyogenes, $F$. necrogenes, $P$. aeruginosa with the zone of inhibitions of $14.66 \pm 0.33 \mathrm{~mm}, 14.00 \pm 0.57 \mathrm{~mm}, 11.66 \pm 0.33 \mathrm{~mm}, 11.33 \pm 0.57 \mathrm{~mm}$ respectively at a concentration of $200 \mathrm{mg} / \mathrm{ml}$. The least antibacterial activity was reported by the hexane extract against all the tested pathogens. The standard positive control Chloramphenicol was found to possess significantly relatively higher activity against the tested pathogens than the plant extracts.

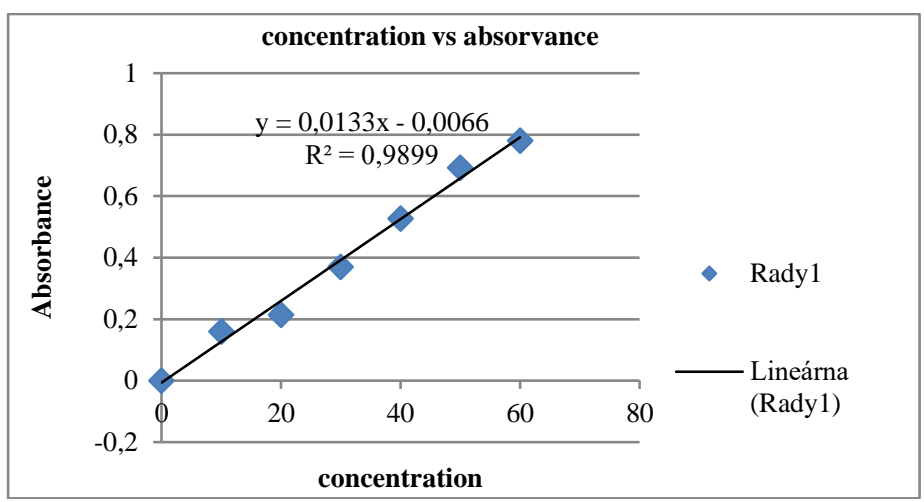

Figure 2 Calibration curve of gallic acid for estimation of total phenolic contents

Table 3 Antibacterial activities leaf extracts of $T$. parthenium against pathogenic bacteria

\begin{tabular}{|c|c|c|c|c|c|}
\hline \multirow{2}{*}{ Extracts } & \multirow{2}{*}{ Conc. $(\mathrm{mg} / \mathrm{ml})$} & \multicolumn{4}{|c|}{ Zone of inhibition with tested pathogen( in mm) } \\
\hline & & S.pyogenes & S. anginosus & P. aeruginosa & F. necrogenes \\
\hline $\mathrm{HE}_{1}$ & & $10.00 \pm 0.57^{\mathrm{Abcd}}$ & $10.66 \pm 0.88^{\mathrm{Acd}}$ & $7.66 \pm 0.33^{\mathrm{Bcd}}$ & $8.33 \pm 0.33^{\mathrm{Bbcd}}$ \\
\hline $\mathrm{CH}_{1}$ & & $10.33 \pm 0.33^{\mathrm{Cbcd}}$ & $10.00 \pm 0.33^{\mathrm{Cbcd}}$ & $8.33 \pm 0.33^{\mathrm{Gbcd}}$ & $9.33 \pm 0.33^{\mathrm{Gcd}}$ \\
\hline $\mathrm{ME}_{1}$ & 100 & $11.66 \pm 0.33^{\text {Dcd }}$ & $12.66 \pm 0.88^{\mathrm{Dd}}$ & $9.66 \pm 0.33^{\mathrm{Ed}}$ & $10.66 \pm 0.33^{\mathrm{Ed}}$ \\
\hline $\mathrm{AQ}_{1}$ & & $11.00 \pm 0.00^{\mathrm{Hcd}}$ & $12.00 \pm 0.00^{\mathrm{Hcd}}$ & $9.00 \pm 0.00^{\mathrm{Fc} \mathrm{d}}$ & $9.66 \pm 0.33^{\mathrm{Fd}}$ \\
\hline $\mathrm{HE}_{2}$ & & $12.00 \pm 0.57^{\text {Qad }}$ & $13.00 \pm 0.57^{\mathrm{Qd}}$ & $8.66 \pm 0.33^{\text {Id }}$ & $9.33 \pm 0.33^{\mathrm{Icd}}$ \\
\hline $\mathrm{CH}_{2}$ & & $12.33 \pm 0.33^{\text {Lacd }}$ & $13.00 \pm 0.57^{\mathrm{Ld}}$ & $9.33 \pm 0.33^{\mathrm{Nd}}$ & $10.00 \pm 0.57^{\mathrm{Nd}}$ \\
\hline $\mathrm{ME}_{2}$ & 150 & $13.33 \pm 0.88^{\mathrm{Jacd}}$ & $13.66 \pm 1.45^{\mathrm{Jad}}$ & $11.000 .57^{\mathrm{Tad}}$ & $11.66 \pm 0.33^{\mathrm{Tad}}$ \\
\hline $\mathrm{AQ}_{2}$ & & $13.00 \pm 0.57^{\mathrm{Rad}}$ & $13.66 \pm 0.66^{\mathrm{Rad}}$ & $10.66 \pm 0.66^{\mathrm{Yad}}$ & $11.33 \pm 0.33^{\mathrm{Ycd}}$ \\
\hline $\mathrm{HE}_{3}$ & & $13.6 \pm 0.33^{\mathrm{Zad}}$ & $14.00 \pm 0.00^{\mathrm{Zad}}$ & $10.00 \pm 0.57^{\mathrm{Pad}}$ & $11.00 \pm 0.00^{\text {Pacd }}$ \\
\hline $\mathrm{CH}_{3}$ & & $14.00 \pm 0.57^{\mathrm{Sad}}$ & $14.66 \pm 0.33^{\mathrm{Sad}}$ & $11.33 \pm 0.57^{\mathrm{Kad}}$ & $11.66 \pm 0.33^{\text {Kabd }}$ \\
\hline $\mathrm{ME}_{3}$ & 200 & $15.00 \pm 0.00^{\mathrm{Tabd}}$ & $15.66 \pm 0.33^{\mathrm{T} \text { ade }}$ & $12.00 \pm 0.00^{\mathrm{Wad}}$ & $12.66 \pm 0.33^{\text {Wabd }}$ \\
\hline $\mathrm{AQ}_{3}$ & & $14.00 \pm 0.57^{\mathrm{Uad}}$ & $15.33 \pm 0.33^{\mathrm{Uad}}$ & $11.66 \pm 0.88^{\mathrm{Xad}}$ & $12.00 \pm 0.00^{\text {Xabd }}$ \\
\hline CHLO & 0.025 & $22.00 \pm 1.00^{\text {abce }}$ & $23.00 \pm 0.57^{\text {abce }}$ & $18.00 \pm 1.15^{\text {abce }}$ & $20.00 \pm 0.00^{\text {abce }}$ \\
\hline
\end{tabular}

Legend: Values are expressed as Mean \pm standard deviations $(\mathrm{n}=3)$,analysis was performed with One-Way ANOVA followed by Turkey test; Significant at $\mathrm{P} \leq 0.05 ;{ }^{\text {a }}$ compared to $100 \mathrm{mg} / \mathrm{ml}$, ${ }^{\mathrm{b}}$ compared to $150 \mathrm{mg} / \mathrm{ml},{ }^{\mathrm{c}}$ compared to $200 \mathrm{mg} / \mathrm{ml}$, ${ }^{\text {d }}$ compared to Chloramphenicol( positive control), ${ }^{\mathrm{e}}$ compared to negative control. Mean values \pm standard deviations followed by the same small letter superscript within the same column are not significant different at $\mathrm{p}>0.05$. Likewise, mean values \pm standard deviations followed by the same capital letter superscript within the same row are not significant different at $\mathrm{p}>0.05$. HE - Hexane, CH - chloroform, ME - Methanol; AQ - water; CHLOChloramphenicol (positive control).

\section{Determination of MIC and MBC}

The MICs leaf extracts of the tested plants are presented in Tab. 4. The MIC values ranged from 33.33 to $83.33 \mathrm{mg} / \mathrm{ml}$ for the four plant extracts tested. The lowest MIC value was observed with methanol extract against two pathogens. Among the four strains tested, S. anginosus $(33.33 \mathrm{mg} / \mathrm{ml})$ and S. pyogenes $(33.33 \mathrm{mg} / \mathrm{ml})$ were found more susceptible to the methanol extract of $T$. parthenium followed by $F$. necrogenes. The $P$. aeruginosa was observed to be most resistant to all the extracts tested. The MBCs of extracts of $T$. parthenium Leaf are presented in Tab. 5. Various degrees of MBCs were displayed by the four extracts of the plant. The lowest MBC was observed in methanol extract against $S$. anginosus $(41.66 \mathrm{mg} / \mathrm{ml})$ and $S$. pyogenes $(41.66 \mathrm{mg} / \mathrm{ml})$. The $P$. aeruginosa was found to be most resistant to all the extracts tested.
Table 4 The Minimum Inhibitory Concentration $(\mathrm{mg} / \mathrm{ml})$ of different extracts of T. parthenium leaves

Bacterial pathogens

S. anginosus

S. pyogenes

F. necrogenes

P. aeruginosa

MIC of leaf extracts of $T$. parthenium $(\mathrm{mg} / \mathrm{ml})$

Legend: $\quad \mathrm{MIC}=$ Minimum Inhibitory Concentration, HE-Hexane, $\mathrm{CH}_{-}$ Chloroform, ME-Methanol, AQ-Aqueous extract 
Table 5 The $\mathrm{MBC}$ of the extracts of $\mathrm{T}$. parthenium leaves against pathogenic bacteria

\begin{tabular}{|c|c|c|c|c|}
\hline \multirow{2}{*}{ Bacterial pathogens } & \multicolumn{4}{|c|}{ MBC of leaf extracts of $T$. parthenium $(\mathrm{mg} / \mathrm{ml})$} \\
\hline & $\mathrm{ME}$ & $\mathrm{AQ}$ & $\mathrm{CH}$ & $\mathrm{HE}$ \\
\hline S. anginosus & 41.66 & 50.00 & 66.66 & 66.66 \\
\hline S.pyogenes & 41.66 & 50.00 & 66.66 & 66.66 \\
\hline F.necrogenes & 66.66 & 66.66 & 83.33 & 83.33 \\
\hline P.aeruginosa & 83.33 & 83.33 & 100 & 100 \\
\hline
\end{tabular}

Legend: $\mathrm{MBC}=$ Minimum Bactericidal Concentration, HE-Hexane, $\mathrm{CH}-$ Chloroform, ME-Methanol, AQ-Aqueous extract

\section{DISCUSSION}

Our study reported the preliminary phytochemical analysis, estimation of total phenolic content and antibacterial activity of $T$. parthenium leaves against four pathogenic bacteria such as $S$. anginosus, $S$. pyogenes, $F$. necrogenes and $P$. aeruginosa. The qualitative analysis of phytochemicals revealed that the leaf extracts of the investigated plant comprise of phenolics, tannins, flavonoids, terpenoids and cardiac glycoside. Previous studies reported the presence of sesquiterpene lactones (Bohlmann and Zdero, 1982, Milbrodt et al., 1997), flavonoids (Williams et al., 1999), and essential oils (Akpulat $\boldsymbol{e t}$ al., 2005) in $T$. parthenium. There are several studies published from other countries on the antibacterial activity of $T$. parthenium. However, no study was found concerning antibacterial activity of the investigated plant in Ethiopia. This is because the composition of bioactives may be altered by the soil composition of different countries (De Zoysa et al., 2019). Moreover, we used four solvents for extraction based on their increasing polarity and four bacterial pathogens were used for the investigation. Our study plant has never been investigated against the pathogen $F$. necrogenes which has been known to cause acute and recurring sore throat and respiratory infections (Aliyu et al., 2004, Batty and Wren, 2005) and periodontal diseases (Batty et al., 2004). Hence, the present study was conducted to report the antibacterial activity of $T$. parthenium against certain pathogens using disc diffusion assay and by determining MIC and MBC values. In all abovesaid methods of assays, the antibacterial activity of the extracts from $T$. parthenium leaves displayed that the solvent and aqueous extracts possessed strong activity against the gram positive pathogenic bacteria such as $S$. anginosus, and $S$. pyogenes, than the gram negative bacteria $F$. necrogenes and $P$. aeruginosa. The cell wall structure of the gram positive bacteria (thick layer of peptidoglycan sheets) may be attributed to the higher susceptivity towards the plant extracts (Nester et al., 2004, Kazemi et al., 2012, Kitonde et al., 2013). A previous study showed that the parthenolide from $T$. parthenium leaves and seeds was proved active against gram positive bacteria (Goren et al., 2013). Our finding on the low sensitivity of $P$. aeruginosa towards plant extracts was in agreement with a previous study in which the essential oil of the leaves of T. parthenium exhibited the weakest antibacterial activity against $P$. aeruginosa (Ali et al., 2017). The antibacterial activities of the extracts of the studied plant were found lower than the standard control chloramphenicol due to the crude nature of the plant extracts (Mengiste $\boldsymbol{e t}$ al., 2015). Among the extracts examined, hexane extract showed relatively lesser antibacterial activity than other extracts which may be due to scarce content of antimicrobial constituents. Our study also exhibited that $T$. parthenium leaf is endowed with secondary metabolites such as phenolics, tannin, flavonoid, terpenoids, and cardiac glycoside. The occurrence of these compounds may be accountable for the antibacterial activity of the extracts against tested pathogens. The strongest antibacterial activity shown by methanol extract may be ascribed to its higher TPC. Phenolic constituents also modify the cell morphology by manipulating the osmotic pressure of the cell, therefore disrupting the cytoplasmic membrane and instigating leakage of cell constituents of the pathogenic bacteria (Sivarooban et al., 2008). Overall, the antibacterial activities of crude extracts of $T$. parthenium leaves against bacterial pathogens springs motivation to further carry out extensive studies on antibacterial potential medicinal plants from different parts of Ethiopia.

\section{CONCLUSION}

In the current study, it was found that hexane, chloroform, methanol and aqueous extracts from $T$. parthenium leaves displayed significant antibacterial properties against $S$. anginosus, $S$. pyogenes, $F$. necrogenes and $P$. aeruginosa. Among them, methanol extract had the potential antibacterial activity against all the pathogens. Out of four bacterial pathogens, S. anginosus was found to be most sensitive to the extracts. $P$. aeruginosa was found more resistant to the extracts of $T$. parthenium leaves. The four solvent and aqueous extracts of the investigated plant exhibited varied degree of efficacies against the bacteria which may be owing to the variance in their polarity. The activities of the extracts could be owing to the presence of different phytoconstituents and high total phenolic content. Further comprehensive investigation is required to evaluate broad spectrum of antibacterial effects of $T$. parthenium against pathogenic bacteria.

Acknowledgements: The authors express their deep sense of gratitude to School of Biological Sciences and Biotechnology for providing facilities to accomplish the research work.

\section{REFERENCES}

ADACHUKWU, I.P., OGBONNA, A.O., EZE, F.U. 2013. Phytochemical analysis of paw-paw (Carica papaya L.) leaves. International Journal of Life Sciences Biotechnology and Pharmaceutical Research, 2(3), 348-351.

AHMAD, I., BEG, A. Z. 2010. Antimicrobial and phytochemical studies on Indian medicinal plants against multi drug resistant human pathogens. Journal of Ethnopharmacology, 74(2), 113-123. https://doi.org/10.1016/s03788741(00)00335-4

AJAYI, I.A., AJIBADE, O., ODERINDE, R.A. 2011. Preliminary phytochemical analysis of some plant seeds. Research Journal of Chemical Sciences, 1(3), 58-62. AKPULAT, H., TEPE, B., SOKMEN, A., DAFERERA, D., POLISSIOU, M. 2005. Composition of the essential oils of Tanacetum argyrophyllum (C. Koch) Tvzel. var. argyrophyllum and Tanacetum parthenium (L.) Schultz Bip. (Asteraceae) from Turkey. Biochemistry System and Ecology, 33, 511-516. https://doi.org/10.1016/j.bse.2004.10.006

ALIYU, S.H., MARRIOTT, R.K., CURRAN, M.D. 2004. Real-time PCR investigation into the importance of Fusobacterium necrophorum as a cause of acute pharyngitis in general practice. Journal of Medical Microbiology, 53, 10291035. https://doi.org/10.1099/jmm.0.45648-0.

ANDERSSON, D.I., HUGHES, D. 2010. Antibiotic resistance and its cost: is it possible to reverse resistance? Nature Reviews Microbiology, 8, 260-271. https://doi.org/10.1038/nrmicro2319.

BATTY, A., WREN, M.W. 2005. Prevalence of Fusobacterium necrophorum and other upper respiratory tract pathogens isolated from throat swabs. British Journal of Biomedical Sciences, 62(2), 66-70. https://doi.org/10.1080/09674845.2005.11732687.

BATTY, A., WREN, M.W., GAL, M. 2000. Fusobacterium necrophorum as the cause of recurrent sore throat: comparison of isolates from persistent sore throat syndrome and Lemierre's disease". Journal of Infection, 51(4), 299306. https://doi.org/10.1016/j.jinf.2004.09.013.

BERNATH, J. 2000. Medicinal and Aromatic plants. Flavour Fragrance Journal, 4, 85-89.

BOHLMANN, F., ZDERO, C. 1982. Sesquiterpene lactones and other constituents from Tanacetum parthenium. Phytochemistry, 21, 2543-2549. https://doi.org/10.1016/0031-9422(82)85253-9.

BURT, S. 2004. Essential oils: their antibacterial properties and potential applications in foods. International Journal of Food Microbiology, 94, 223-235. https://doi.org/10.1016/j.ijfoodmicro.2004.03.022

CLSI, 2012. Performance Standard for antimicrobial disc susceptibility tests: Approved Standard, $11^{\text {th }}$ edition. CLSI document M02-A11.32:1.Clinical Laboratory Standard Institute, Wayne, PA.950 West Valley Road, Suite 2500 Wayne, PA 19087 USA.

COSTA, R.S., LINS, M.O., HYARIC, M.L., BARROS, T.F., VELOZO, E.S. 2017. In vitro antibacterial effects of Zanthoxylum tingoassuiba root bark extracts and two of its alkaloids against multiresistant Staphylococcus aureus. Revista Brasileira de Farmacognosia, 27(2), 195-198.

HARBORNE, J. B. 1984. Phytochemical Methods. A Guide to Modern Techniques of Plant Analysis. ISBN: 978-94-009-5570-7. Chapman and Hall Ltd. London.

IZADI, Z., ESNA-ASHARI, M., PIRI, K., DAVOODI, P. 2010. Chemical composition and antimicrobial activity of feverfew (Tanacetum parthenium) essential oil. International Journal of Agriculture Biology, 12, 759-763.

KAZEMI, M., MOUSAVI, E., BANDREZ, N. 2012. Chemical composition and antibacterial activity of the essential oils of Thymus vulgaris and Tanacetum parthenium. Research Journal of Soil Biology. 4(2), 21-31. https://doi.org/10.3923/risb.2012.21.31.

KNIGHT, D.W. 1995. Feverfew: chemistry and biological activity. Natural Products Reports, 12, 271-276. https://doi.org/10.1039/NP9951200271

KITONDE, C.K., FIDAHUSEIN D. S., LUKHOBA C.W., JUMBA M.M. 2013. Antimicrobial activity and phytochemical study of Vernonia Glabra (Steetz) Oliv. 
\& Hiern. in Kenya. African Journal of Traditional Complementary and Alternative Medicine, 10(1), 149-157. https://doi.org/10.4314/ajtcam.v10i1.20

MARILENA, C., BERSANI, C., COMI, G. 2005. Impedance measurements to study the antimicrobial activity of essential oils from Asteraceae. International Journal of Food Microbiology, 95(2), 187-195.

MILBRODT, M., SCHRODER, F., KONIG, W. 1997. 3,4--Epoxy-8deoxycumambrin B, A sesquiterpene lactone from Tanacetum parthenium. Phytochemistry, 44, 471-474.

NESTER, E.W., ANDERSON, D.G., ROBERTS, C.E., PEARSALl, N.N., NESTER, M.T. 2004. Microbiology: A Human Perspective. 4th ed. New York: McGraw-Hill;

SASIKUMAR, J.M., THAYUMANAVAN, THA, SUBASHKUMAR, R, JANARDHANAN, K, LAKSHMANAPERUMALSAMY, P. 2007. Antibacterial activity of some ethnomedicinal plants from the Nilgiris, Tamil Nadu, India. Natural Product Radiance. 6(1): 34-39. https://doi.org/http://nopr.niscair.res.in/handle/123456789/7842

SHAHHOSEINI, R., AZIZI, M., ASILI, J., MOSHTAGHI, N., SAMIEI, L. 2019. Comprehensive assessment of phytochemical potential of Tanacetum parthenium (L.): phenolic compounds, antioxidant activity, essential oil and parthenolide. Journal of Essential Oil Bearing Plants, 22, 614-629. https://doi.org/10.1080/097206.

SHAIK, S., NISHA, S., ASHLEY, N. 2011. Comparison of the selected secondary metabolites contents present in the cancer-Bush Lessertia frutescens L. extracts. African Journal of Traditional, Complementary and Alternative Medicines, 8(4), 429-434. https://doi.org/10.4314/ajtcam.v8i4.14

SINGLETON, V. L., ORTHOFER, R., LAMUELA-RAVENTOS, R. M. 1999. Analysis of total phenols and other oxidation substrates and antioxidants by means of folin-ciocalteu reagent. Methods in Enzymology, 299,152-178. https://doi.org/10.1016/s0076-6879(99)99017-1

SIVAROOBAN, T., HETTIARACHCHY, N.S., JOHNSON, M.G. 2008. Transmission electron microscopy study of Listeria monocytogenes treated with in combination with either grape seed or green tea extract. Journal of Food Protection, 71, 2105-2109. https://doi.org/10.4315/0362-028x-71.10.2105

TSURUGA, M. NAKAJIMA, H. MAGAE, J. 2007. Immunosuppressive activity of4-O-Methylascochlorin, The Journal of Antibiotics, 60, 20-26. https://doi.org/10.1038/ja.2007.3

WILLIAMS, C.A., HARBORNE, J.B., GEIGER, H., HOULT, J.R. 1999. The flavonoids of Tanacetum parthenium and T. vulgare and their anti-inflammatory properties. Phytochemistry, 51, 417-423. https://doi.org/10.1016/s00319422(99)00021-7 